Revista Brasileira de Cartografia

ISSN 1808-0936 | https://doi.org/10.14393/revbrascartogr

Sociedade Brasileira de Cartografia, Geodésia, Fotogrametria e Sensoriamento Remoto

\title{
Sensibilidade do NDVI para a Identificação do Regime de Fluxo em Rios de Primeira Ordem: Estudo de Caso no Sudoeste do Paraná
}

\author{
NDVI Sensitivity for the Identification of the Flow Regime in First-order Rivers: a Case \\ Study in Southwest Paraná
}

Fabiano André Marion ${ }^{1}$, Tony Vinicius Moreira Sampaio ${ }^{2}$ e Fabio Marcelo Breunig ${ }^{3}$

1 Universidade Estadual do Oeste do Paraná, Curso de Geografia, Francisco Beltrão - PR, Brasil. E-mail.

fabiano.marion@unioeste.br

ORCID: https://orcid.org/0000-0002-8762-315X

2 Universidade Federal do Paraná, Departamento de Geografia, Curitiba - PR, Brasil. E-mail. tony2sampaio@gmail.com

ORCID: https://orcid.org/0000-0002-3339-9025

3 Universidade Federal de Santa Maria, Departamento de Engenharia Florestal, Frederico Westphalen - RS, Brasil. E-mail.

fabiobreunig@gmail.com

ORCID: https://orcid.org/0000-0002-0405-9603

Recebido: 02.2020 | Aceito: 05.2020

Resumo: O mapeamento da rede de drenagem frequentemente apresenta problemas na classificação de seu regime de fluxo e na estimativa da extensão dos rios de primeira ordem, sobretudo em áreas florestadas. Entretanto, a vegetação associada aos rios pode dar indícios sobre o tipo de fluxo presente, a partir da análise dos índices de vegetação, entre os quais, o NDVI (Normalized Difference Vegetation Index) é o mais utilizado mundialmente. O objetivo deste trabalho foi de avaliar o potencial de aplicação do NDVI da vegetação associada a rios de primeira ordem para diferenciar a drenagem perene da intermitente. A área de estudo apresenta floresta estacional semidecidual e abrange parte dos municípios de Francisco Beltrão, Renascença e Marmeleiro, no sudoeste do estado do Paraná. Foram identificados em campo 20 rios de primeira ordem perenes e 20 intermitentes, com vegetação nativa arbórea associada. Uma vez identificados na base cartográfica, foram gerados buffers de 0-15 m e 15-30 m, a partir do canal de drenagem. Estes buffers foram utilizados para obtenção dos valores de NDVI calculados a partir de imagens RapidEye referente as datas de 8/1/2018 (T1) e 10/9/2018 (T2). Foi verificada a diferença de NDVI entre os dois períodos ( $\Delta$-NDVI) em cada buffer. Para verificar se as diferenças foram significativas, foi aplicado o teste de Mann-Witney. Observou-se que os valores de NDVI acompanharam as características climáticas, apresentando valores próximos a 0,9 em T1 e que, em alguns casos, os valores decaíram até $0,6 \mathrm{em}$ T2. Os valores de $\Delta$-NDVI ao longo dos rios intermitentes foram maiores, comprovando o pressuposto inicial, contudo as diferenças não foram estatisticamente significativas.

Palavras-chave: Mapeamento da rede de drenagem. Sensoriamento remoto da vegetação. Índices de vegetação. Floresta estacional semidecidual.

\begin{abstract}
Drainage network mapping frequently has problems to classify flow regime and extent of first-order rivers, especially in forested areas. However, the vegetation associated with the rivers can be a proxy to their flow regime by the application of the vegetation index, among which, the NDVI (Normalized Difference Vegetation Index) is the most used worldwide. The objective of this paper was to evaluate the potential application of NDVI to vegetation associated with first order rivers to differentiate between perennial and intermittent drainage. The study area presents semideciduous seasonal forest and covers part of the municipalities of Francisco Beltrão, Renascença, and Marmeleiro, in the southwest of the Paraná state. Twenty perennial and twenty intermittent first-order rivers were identified in the field with tree native vegetation. Once identified in the cartographic base, buffers of 0-15 m and 15-30 m were generated next to the drainage channel. These buffers were used to obtain the NDVI values, calculated from RapidEye images for the dates of 8/1/2018 (T1) and 10/9/2018 (T2). The difference in NDVI was verified between the two periods ( $\Delta$-NDVI) for each buffer. To verify whether the differences were significant, the Mann-Witney test was applied. It was observed that the NDVI values followed the climatic characteristics, showing values close to 0.9 (T1), and sometimes this value decreased up to 0.6 (T2). The $\Delta$-NDVI values along the intermittent rivers were higher, proving the initial hypothesis; however, the differences were not statistically significant.
\end{abstract}

Keywords: Drainage network mapping. Remote sensing of vegetation. Vegetation index. Semideciduous seasonal forest. 


\section{INTRODUÇÃO}

A rede de drenagem tem nos rios de primeira ordem (que vão da nascente até a primeira bifurcação) porção significativa de seu comprimento e de seu volume de descarga (LARNED et al., 2010). Entretanto, no mapeamento da rede de drenagem as bases cartográficas frequentemente apresentam problema na classificação de seu regime de fluxo e na estimativa da sua extensão, sobretudo em áreas florestadas (FRITZ et al., 2013; GONZÁLEZ-FERRERAS; BARQUÍN, 2017). Por estarem situados em áreas mais elevadas, os rios de primeira ordem são mais afetados pelas flutuações do nível freático e, por isso, muitos são propensos à secagem natural em alguns períodos do ano (FRITZ et al., 2013).

A correta classificação do regime de fluxo no mapeamento da rede de drenagem, em perene ou intermitente, é indispensável por constituir fator importante para compreensão dos ecossistemas aquático e terrestre de seu entorno (WILLIAMSON et al., 2015) e por ser ferramenta-chave para monitoramento, modelagem e tomada de decisão (FRITZ et al., 2013).

O método mais eficiente para identificar o regime de fluxo é a pesquisa de campo que, por ser trabalhosa e onerosa, não é aplicável para o mapeamento de grandes áreas. Nesse caso, são utilizadas técnicas de interpretação a partir de imagens aéreas e/ou extração automática a partir de modelos digitais de elevação (MDE). Esses métodos também apresentam problemas, conforme apontam pesquisas realizadas por Lin et al. (2006), Lima e Cunha (2014), Tomazoni et al. (2011), Fernández et al. (2012), Sampaio e Augustin (2014), Bosquilia et al. (2016) e Sousa e Sampaio (2018), sobretudo em rios de primeira ordem (SAMPAIO; AUGUSTIN, 2014).

A reduzida largura e extensão e a incisão rasa de seu canal tornam difícil a identificação do regime de fluxo dos rios de primeira ordem (FRITZ et al., 2013), dificuldade que se acentua em presença de vegetação arbórea densa (GONZÁLEZ-FERRERAS; BARQUÍN, 2017), o que exige a adoção de novas abordagens e dados que facilitem o correto mapeamento dos rios de primeira ordem e a identificação de seu regime de fluxo.

Nesse sentido, a própria vegetação nativa associada aos rios pode dar indícios sobre o seu regime de fluxo. Isto porque, no período de estiagem, o rio intermitente seca e a vegetação ali presente deixa de ter acesso à água superficial, o que pode afetar suas funções morfológicas e fisiológicas. Este mesmo processo não ocorre com a vegetação presente às margens de rios perenes, a qual continua a ter água disponível, portanto estará menos sujeita às condições de déficit hídrico (BARRON et al., 2014).

As condições de estresse por déficit hídrico são passíveis de mensuração por meio de técnicas de sensoriamento remoto, pelo uso de dados provenientes de diferentes sensores, localizados em diversas plataformas e expressos por meio de índices de vegetação - IV (DONOHUE; MCVICAR; RODERICK, 2009). IV são medidas radiométricas adimensionais, as quais indicam a abundância relativa e a atividade da vegetação, incluindo índice de área foliar (IAF), porcentagem de cobertura verde, teor de clorofila, fitomassa e radiação fotossinteticamente ativa absorvida (JENSEN, 2009). O estresse hídrico causa redução nas taxas biofísicas da vegetação (fotossíntese e transpiração), o que resulta em queda substancial do IV (BONIFACIO; DUGDALE; MILFORD, 1993). O NDVI (Normalized Difference Vegetation Index), criado por Rouse et al (1973), é o IV mais utilizado mundialmente (AYANLADE, 2017; XUE; SU, 2017) e a sua relação com o vigor da vegetação associada às áreas com disponibilidade hídrica já foi identificada.

Barron et al. (2014) e Barbosa, Carvalho e Camacho (2017) delinearam áreas de vegetação que sustentam altos valores de NDVI durante a estação seca, dentro de um ciclo meteorológico anual. Os autores constataram que a vegetação dessas áreas apresentou valores de NDVI divergentes espacial e/ou temporalmente das áreas circundantes, devido à associação com nascentes e rios perenes. Albuquerque et al. (2014), Machado et al. (2014) e Brito et al. (2017) observaram que no período de estiagem, nas áreas com disponibilidade hídrica os valores de NDVI permanecem elevados, ao contrário das áreas sem disponibilidade. Huete et al. (2006) explicam que isso ocorre porque a disponibilidade hídrica das áreas florestais próximas aos rios proporciona uma estabilidade na atividade fotossintética e, consequentemente, na produção de fitomassa foliar mantida (ou com pequena queda) na época seca.

Em especial, a floresta estacional semidecidual, encontrada na área de estudo, tem como principal característica fisionômica o fato de 20 a 50\% das árvores do dossel da floresta serem caducifólias, ou seja, 
perderem suas folhas ao entrar em repouso fisiológico na estação desfavorável mais seca ou fria (IBGE, 2012). Em consequência disso, nas áreas florestais com presença de espécies deciduais, há perda de fitomassa durante o inverno, o que reduz a oferta de pigmentos fotossintetizantes, fazendo com que a refletância na faixa do vermelho seja ligeiramente superior, enquanto a faixa do infravermelho tem grande redução em sua refletância e, por isso, valores de NDVI mais baixos (GAIDA et al., 2016; CORDEIRO et al., 2017).

Rosemback et al. (2010), Cordeiro et al. (2017), Costa e Guasselli (2017) e Quesada et al. (2017) analisaram a variação do NDVI por meio de séries temporais em áreas de floresta estacional semidecidual e encontraram valores menores de NDVI para o inverno e maiores no verão. Desses autores, apenas Quesada et al. (2017) analisaram a relação do NDVI com a proximidade do rio e verificaram maiores valores do índice nas áreas próximas aos rios, sem levar em consideração o regime de fluxo na realização do estudo. Dessa forma, esta pesquisa adota como pressuposto que as alterações nos valores de NDVI podem ser utilizadas como indicativos do regime de fluxo associado aos rios de primeira ordem. O objetivo deste trabalho foi de avaliar o potencial de aplicação do NDVI da vegetação associada a rios de primeira ordem para diferenciar a drenagem perene da intermitente.

\section{MATERIAL E MÉTODOS}

\section{1 Área de estudo}

A área de estudo localiza-se no sudoeste do estado do Paraná (SO/PR), abrangendo parte dos municípios de Francisco Beltrão, Marmeleiro e Renascença (Figura 1), com amplitude altimétrica entre 510 e $780 \mathrm{~m}$. Situa-se no terceiro planalto paranaense, formado por rochas efusivas básicas e ácidas pertencentes à formação Serra Geral (Jurássico superior - Cretáceo inferior) (BREA; ZUCOL, 2011). Está inserida no Planalto de Francisco Beltrão, que apresenta dissecação média, topos alongados, vertentes convexas, vales em "V" aberto e declividade predominante entre 12-30\% (SANTOS et al., 2009). A formação florestal encontrada é a floresta estacional semidecidual, predominante nas regiões norte e oeste do estado do Paraná entre 200 e $800 \mathrm{~m}$ de altitude e apresenta florística diferenciada e empobrecida em relação às formações ombrófilas (RODERJAN et al., 2002).

Figura 1 - Localização da área de estudo - Paraná - Brasil.

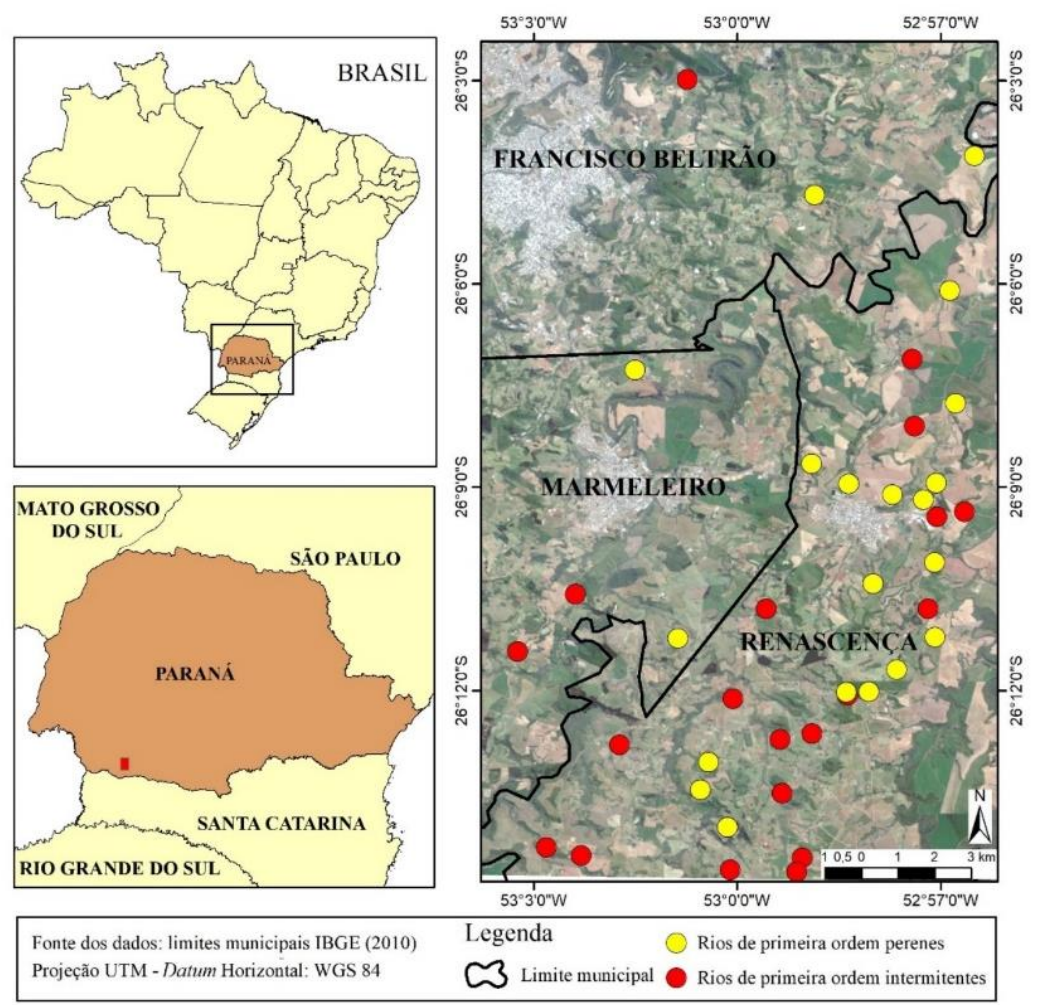

Fonte: Os autores (2020). 
A precipitação no SO/PR é influenciada principalmente pelo relevo. As regiões mais altas, próximas à divisa com Santa Catarina, registram médias anuais de até $2.170 \mathrm{~mm}$, enquanto as porções mais baixas, próximas ao rio Iguaçu, registram média de até $1.920 \mathrm{~mm}$ (CALDANA et al., 2019). Segundo a classificação de Köppen-Geiger, a maior parte do SO/PR abrange o clima Cfa (subtropical, com verão quente), onde está localizada a área de estudo e, nas áreas mais altas, o clima Cfb (temperado, com verão ameno) (ALVARES et al., 2013). Conforme dados históricos da estação meteorológica de Francisco Beltrão (IAPAR, 2019), a temperatura média anual é de $19,2^{\circ} \mathrm{C}$ (média máxima $=26^{\circ} \mathrm{C}$ e média mínima $=14^{\circ} \mathrm{C}$ ), sendo o verão chuvoso, com temperatura média de $24,2^{\circ} \mathrm{C}$, e o inverno geralmente seco, com temperatura média de $15,1^{\circ} \mathrm{C}$, sujeito a geadas. O mês de janeiro apresenta média acumulada de 190,7 $\mathrm{mm}$ mensais e fevereiro, $170 \mathrm{~mm}$, enquanto os meses de julho e agosto apresentam a menor média acumulada mensal, 132,1 e 112,1 mm, respectivamente (IAPAR, 2019) (Figura 2).

Figura 2 - Distribuição anual das médias mensais de temperatura $\left({ }^{\circ} \mathrm{C}\right)$ e de precipitação acumulada $(\mathrm{mm})$ entre 1974 e 2018 e precipitação acumulada em 2018: estação meteorológica de Francisco Beltrão - PR.

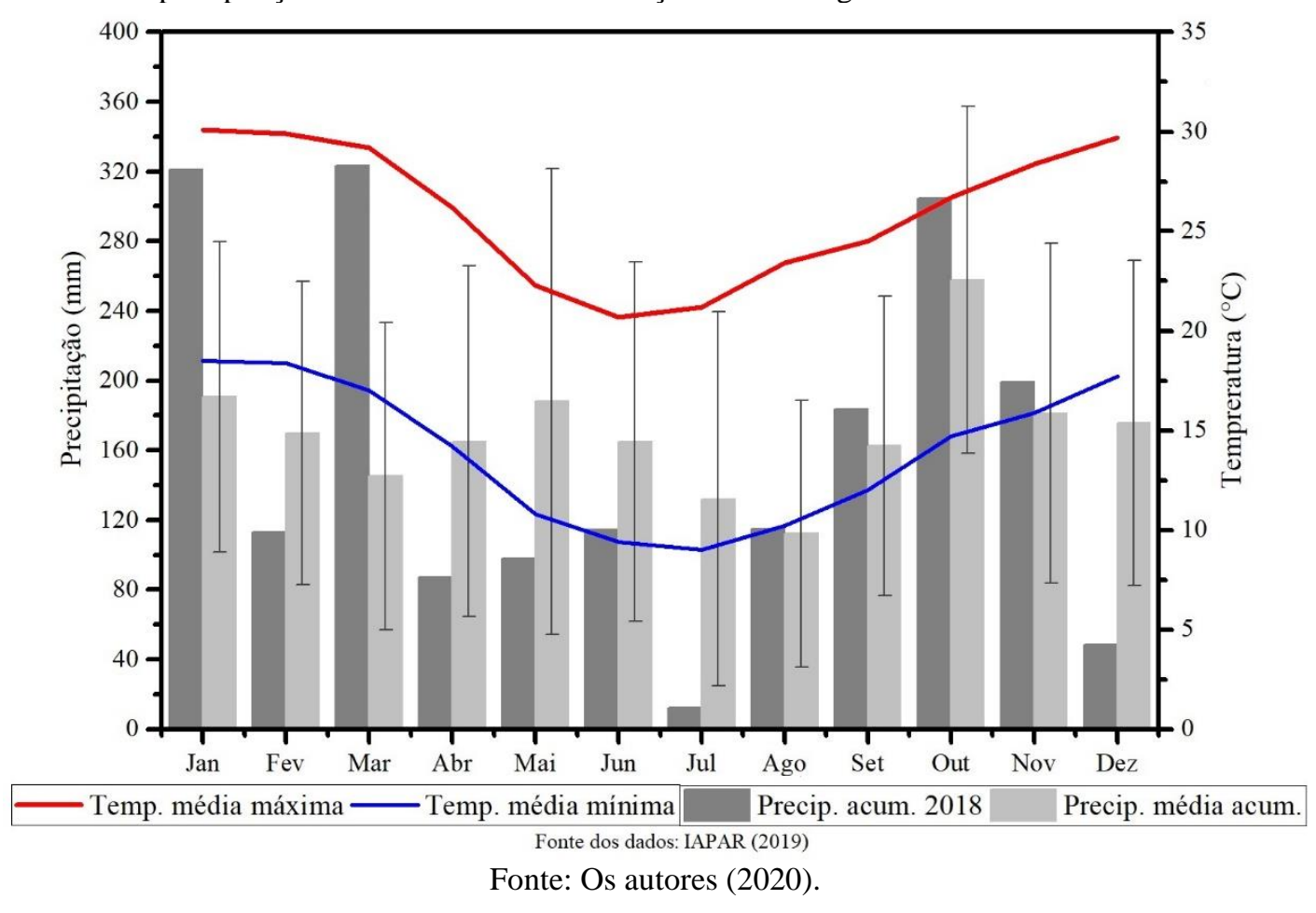

\subsection{Verificações de campo}

Foram visitados 40 pontos: 20 correspondentes a rios perenes e 20 intermitentes. Para o planejamento dos trabalhos de campo foi utilizada a base hidrográfica oficial do Paraná, disponibilizada pelo Instituto de Águas do Paraná (INAPAR, 2011) em formato vetorial. Foram selecionados apenas rios de primeira ordem que apresentam, em pelo menos uma das suas margens, vegetação arbórea nativa numa distância mínima de $50 \mathrm{~m}$. Este critério teve por finalidade permitir que a área de vegetação fosse maior que a área dos buffers a fim de evitar possível mistura de pixels na borda.

Os pontos pré-selecionados foram verificados em campo quanto à existência ou não do fluxo de água no canal. Os trabalhos de campo foram realizados de 20 a 23 de junho e 28 de julho de 2019, com retorno em 11 de agosto de 2019 para completar as informações. Antes da realização dos trabalhos de campo, foram consultadas as informações da estação pluviométrica de Marmeleiro (latitude: 260 09' 08" S e longitude: $53^{\circ}$ 01' 05" W.Gr.) (INAPAR, 2019), para verificar a possível ocorrência de precipitação, nas semanas que antecederam os trabalhos de campo. O objetivo desta consulta foi de garantir que os trabalhos de campo não ocorressem em datas posteriores a eventos esporádicos de precipitação, os quais poderiam promover a ocorrência de fluxos efêmeros. Foi observado o período mínimo de 10 dias sem precipitação para realização dos trabalhos de campo. A Figura 3 representa os valores da precipitação e, destacados com retângulo 
vermelho, os dias em que foram realizadas as verificações em campo.

Figura 3 - Precipitação diária registrada entre $1^{\circ}$ de junho e 11 de agosto de 2019 pela estação pluviométrica de Marmeleiro - PR.

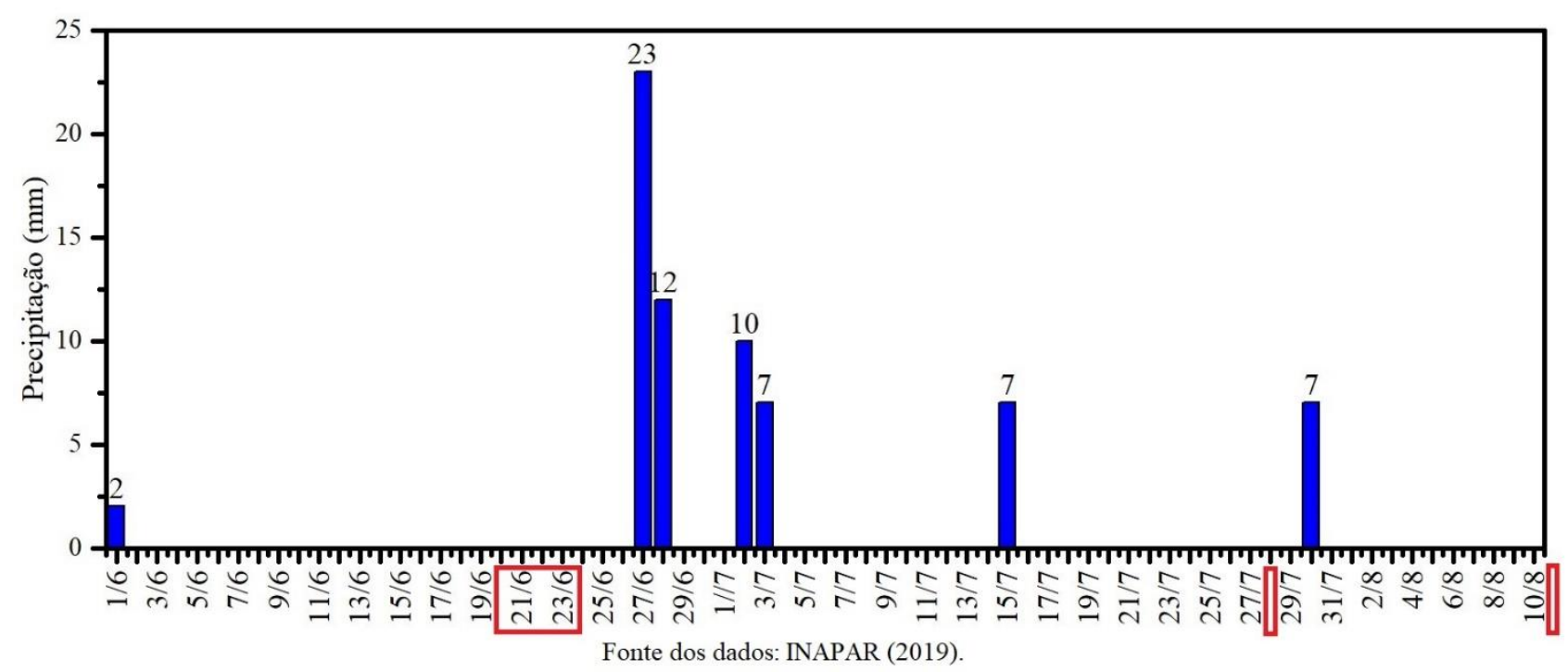

Fonte: Os autores (2020).

\subsection{Aquisição, processamento das imagens e índices de vegetação}

Para encontrar os maiores e menores valores de NDVI da vegetação associada a rios de primeira ordem, primeiramente, foram verificadas as cenas do sensor RapidEye disponibilizadas pela empresa Planet Labs (PLANET TEAM, 2018), sem presença de nuvens e que encobrem a área de estudo no decorrer do ano de 2018. A imagem que apresentou os maiores valores foi denominada de $\mathrm{T} 1 \mathrm{e}$, a imagem com os menores valores, denominada de T2. As imagens obtidas já apresentam correção geométrica e ortorretificação (produto RapidEye nível 3 A) com resolução espacial nominal de $5 \mathrm{~m}$, resolução radiométrica de 16 bits e cinco bandas espectrais (em nm): azul (440-510), verde (520-590), vermelho (630-685), borda do vermelho (690-730) e infravermelho próximo (790-850) (RAPIDEYE, 2016).

Posteriormente, foi realizada a calibração radiométrica das imagens aplicando os parâmetros do modelo FLAASH (fast line-of-sight atmospheric analysis of spectral hypercubes) (EXELIS, 2015), requisito para o uso do referido modelo na correção atmosférica. Para a sua execução foram utilizados os parâmetros da aquisição das imagens, a visibilidade padrão $(50 \mathrm{~km})$, modelo atmosférico subtropical (conforme a estação da imagem) e o modelo de aerossol rural. Depois de realizada a correção, foram gerados os espectros de refletância a partir dos valores médios dos buffers obtidos pela ferramenta "ROIs Statistics". Para gerar os valores de NDVI, proposto por Rouse et al. (1973), foi utilizada a ferramenta "Band Math", conforme mostra a Eq. (1).

$$
N D V I=\frac{(N I R-R)}{(N I R+R)}
$$

onde NIR é a refletância na banda do infravermelho próximo; e, R a na banda do vermelho (Eq. 1)

\subsection{Análise estatística e espacial dos dados}

A base hidrográfica oficial do estado do Paraná, disponibilizada pelo INAPAR (2011), foi corrigida quanto à tipologia dos fluxos a partir de trabalhos de campo. Na base corrigida foram gerados buffers de $15 \mathrm{x}$ $15 \mathrm{~m}$ em um lado da margem de cada canal de drenagem, evitando-se a proximidade com outros cursos da água. A distância demarcada, a partir do canal, foi entre 0 e $15 \mathrm{~m}$ (buffer 1), e, entre 15 e $30 \mathrm{~m}$ (buffer 2) 
(Figura 4). Optou-se por utilizar na pesquisa a distância de até $30 \mathrm{~m}$ por ser considerada como funcional da vegetação ribeirinha, em rios de primeira ordem, conforme apontam Jayasuriya, Germain e Bevilacqua (2018).

Figura 4 - Medidas e posição dos buffers conforme o regime de fluxo e a data das imagens: T1 (maiores valores de NDVI) e T2 (menores valores de NDVI).
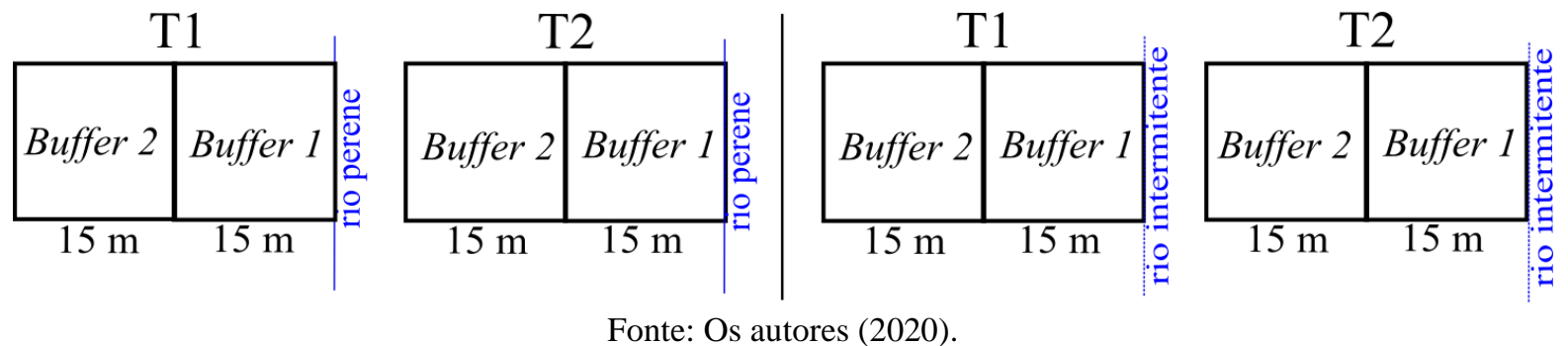

Fonte: Os autores (2020).

Os buffers foram exportados para o software Envi 5.0 utilizado para extrair os valores de NDVI por pixel para as duas imagens (T1 e T2). Foi utilizada a ferramenta ROI (region of interest) e os arquivos salvos em formato ASCII. A normalidade sobre os valores absolutos de NDVI foi verificada pela aplicação do teste de Shapiro-Wilk, com o nível de significância de 0,05 , para cada um dos 8 conjuntos amostrais de buffers. Esta análise teve por finalidade definir o tipo de teste comparativo para as médias a ser utilizado: $t$ de Student ou Mann-Whitney (amostras não paramétricas).

No software Microsoft Office Excel, foram calculados os valores médios de NDVI para cada buffer e realizadas as análises estatísticas descritivas para os valores de média, desvio padrão, soma, mínimo, mediana e máximo. Para calcular as diferenças entre os períodos ( $\Delta$-NDVI), a fim de verificar se elas são maiores junto aos rios perenes e entre os buffers 1, foi realizada a subtração dos valores médios de cada buffer entre T1 e T2 e realizada a análise da estatística descritiva e inferencial. A síntese dos procedimentos utilizados para análise estatística inferencial encontra-se na Figura 5.

Figura 5 - Organograma dos testes para a análise estatística inferencial: $\Delta$ (diferença entre T1 e T2) e $\overline{\mathbf{X}}$ (média dos valores de NDVI em cada buffer).

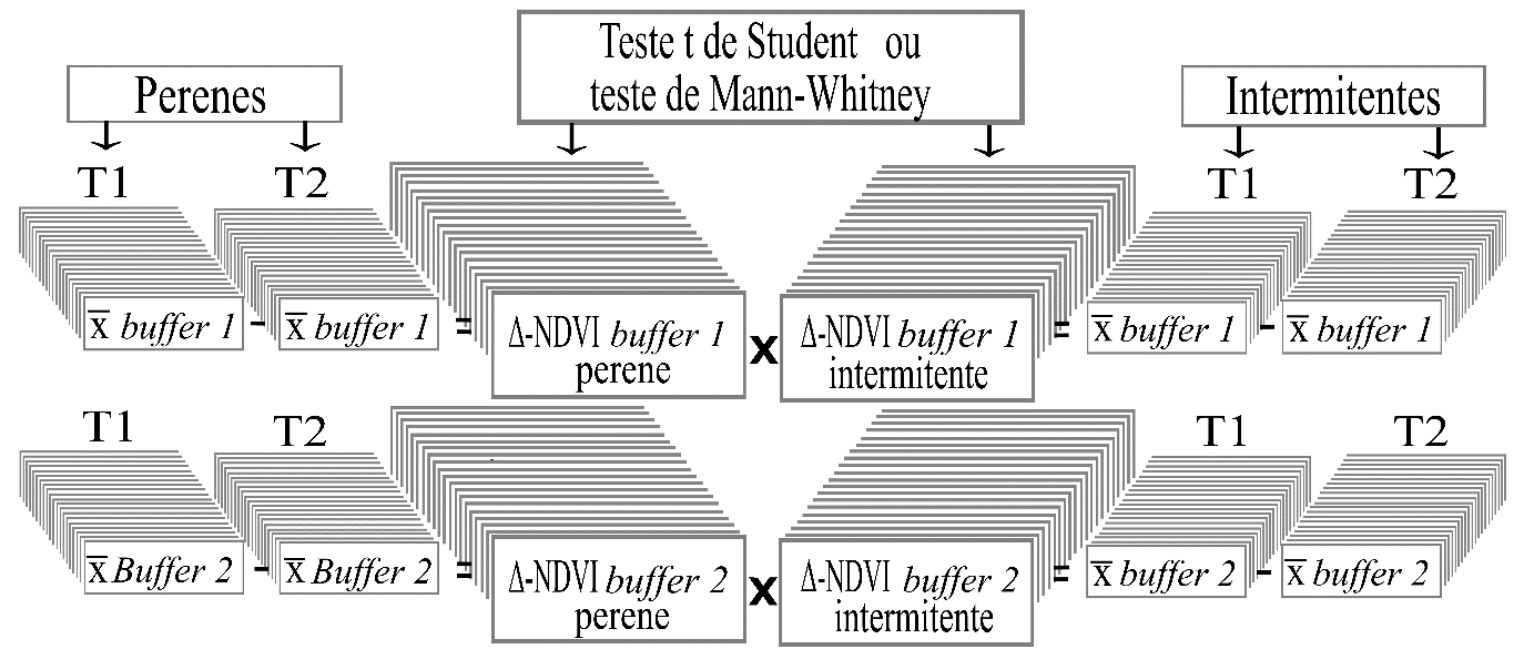

Fonte: Os autores (2020).

\section{RESULTADOS E DISCUSSÃO}

\subsection{Análise dos espectros de refletância}

Com objetivo de encontrar os maiores e menores valores de NDVI, de forma a obter o maior valor de $\Delta$-NDVI possível, foram analisadas sete imagens disponíveis para a área de estudo. Os maiores valores de NDVI da vegetação associada a rios de primeira ordem foram encontrados na imagem de 8/1/2018, denominada de T1 e, os menores valores na imagem de 10/9/2018, denominada de T2. Essa variação temporal 
é perceptível também ao analisar os espectros de refletância das bandas RapidEye, tanto para a vegetação associada a rios perenes, quanto intermitentes. Os valores de refletância são representados nos gráficos em função do comprimento de onda central de cada banda (em nm): azul (475), verde (555), vermelho (660), borda do vermelho (710) e infravermelho próximo (820) (Figura 6).

Figura 6 - Espectros de refletância para os buffers amostrais ao longo dos rios: a) perenes; b) intermitentes.
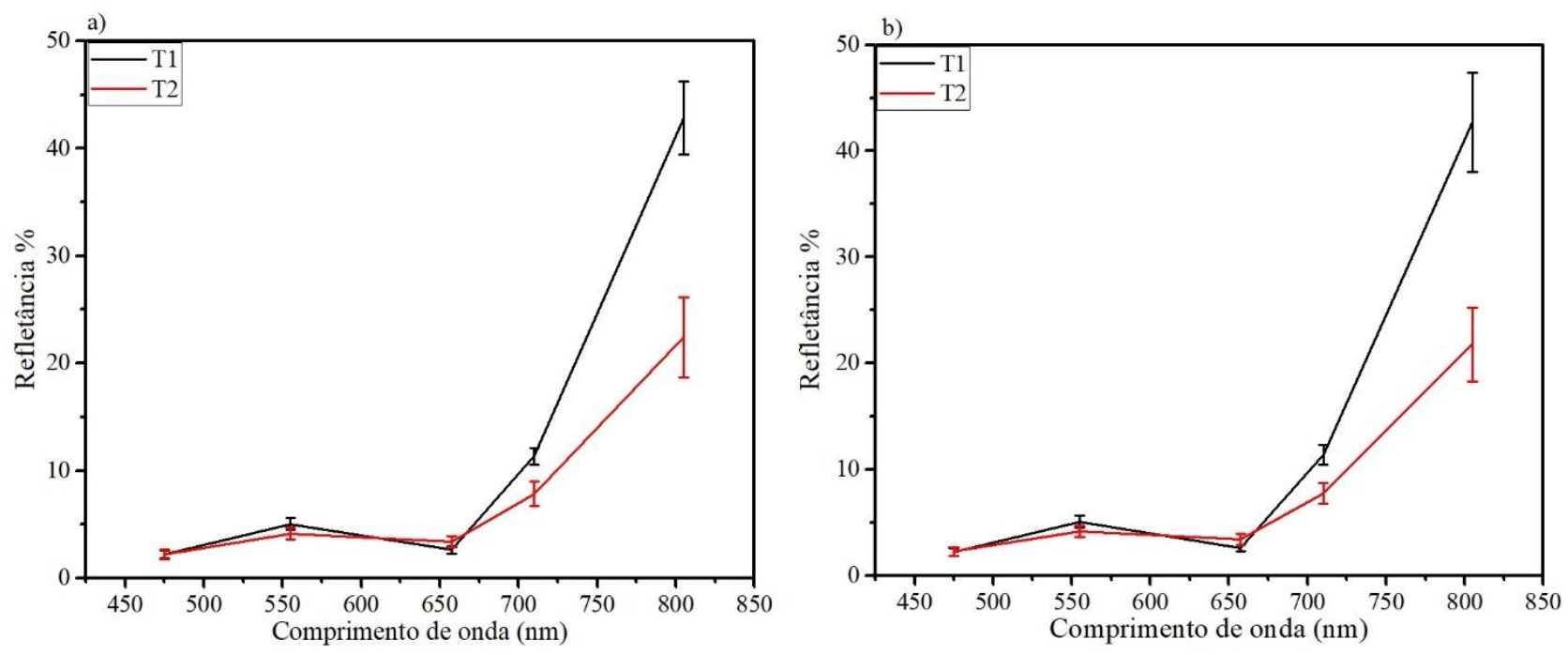

Fonte: Os autores (2020).

Nos comprimentos de onda relativos à região do visível do espectro eletromagnético (azul, verde e vermelho), os valores de refletância são baixos em ambas as datas analisadas. A partir dos $660 \mathrm{~nm}$ foi verificado significativo acréscimo nos valores de refletância, a qual é maior na imagem T1. Isso ocorre devido ao maior vigor da vegetação florestal nos meses de verão, no qual ela absorve mais radiação solar na faixa do vermelho e reflete, fortemente, na faixa do infravermelho próximo, em decorrência da incapacidade de os estratos vegetativos em absorverem ou transmitirem esse tipo de radiação (PONZONI; SHIMABUKURO; KUPLICH, 2012).

No inverno (imagem T2) a refletância diminui a partir dos $660 \mathrm{~nm}$, o que ocorre de forma mais acentuada nas áreas florestais com presença de espécies deciduais devido à perda de biomassa, reduzindo a oferta de pigmentos fotossintetizantes. Rosemback et al. (2010), Cordeiro et al. (2017) e Costa e Guasselli (2017), também encontraram forte queda a partir dos $660 \mathrm{~nm}$, entre verão/inverno, ao analisarem áreas de floresta estacional semidecidual.

\subsection{Análise dos valores de NDVI}

Para verificar a distribuição dos dados, foram construídos os histogramas a partir dos valores de NDVI, entre os quais, apenas três dos oito gráficos apresentam distribuição simétrica. Nos histogramas representativos do conjunto de buffers amostrais junto aos rios perenes, a assimetria negativa, na qual a média apresenta-se deslocada à esquerda do centro do gráfico, é encontrada nos gráficos a, b e d. Já para os intermitentes, a assimetria negativa é encontrada nos gráficos a e d (Figura 7).

As variações de frequência entre perenes versus intermitentes é pequena, entretanto ao comparar os períodos $\mathrm{T} 1$ e T2, a frequência apresenta-se mais dispersa nos gráficos c e d, representativos do período T2. A dispersão dos valores de NDVI é maior no inverno (período T2), pois nessa época, a deciduidade da vegetação varia conforme a espécie, o que reflete em valores de NDVI mais heterogêneos no inverno.

O teste de Shapiro-Wilk indicou que dos valores de pixel para os 8 conjuntos de buffers amostrais, apenas 2 conjuntos apresentaram p-value acima de 0,05 , conforme valores da Tabela 1 . Dessa forma, optouse por utilizar testes não paramétricos para verificar se existem diferenças significativas entre o grupo de amostras (perenes versus intermitentes). 
Figura 7 - Histograma com valores de NDVI em cada conjunto de buffers amostrais: a) buffer 1 (0 - 15 m) - T1; b) buffer $2(15-30 \mathrm{~m})$ - T1; c) buffer $1(0-15 \mathrm{~m})$ - T2; d) buffer $2(15-30 \mathrm{~m})$ - T2.
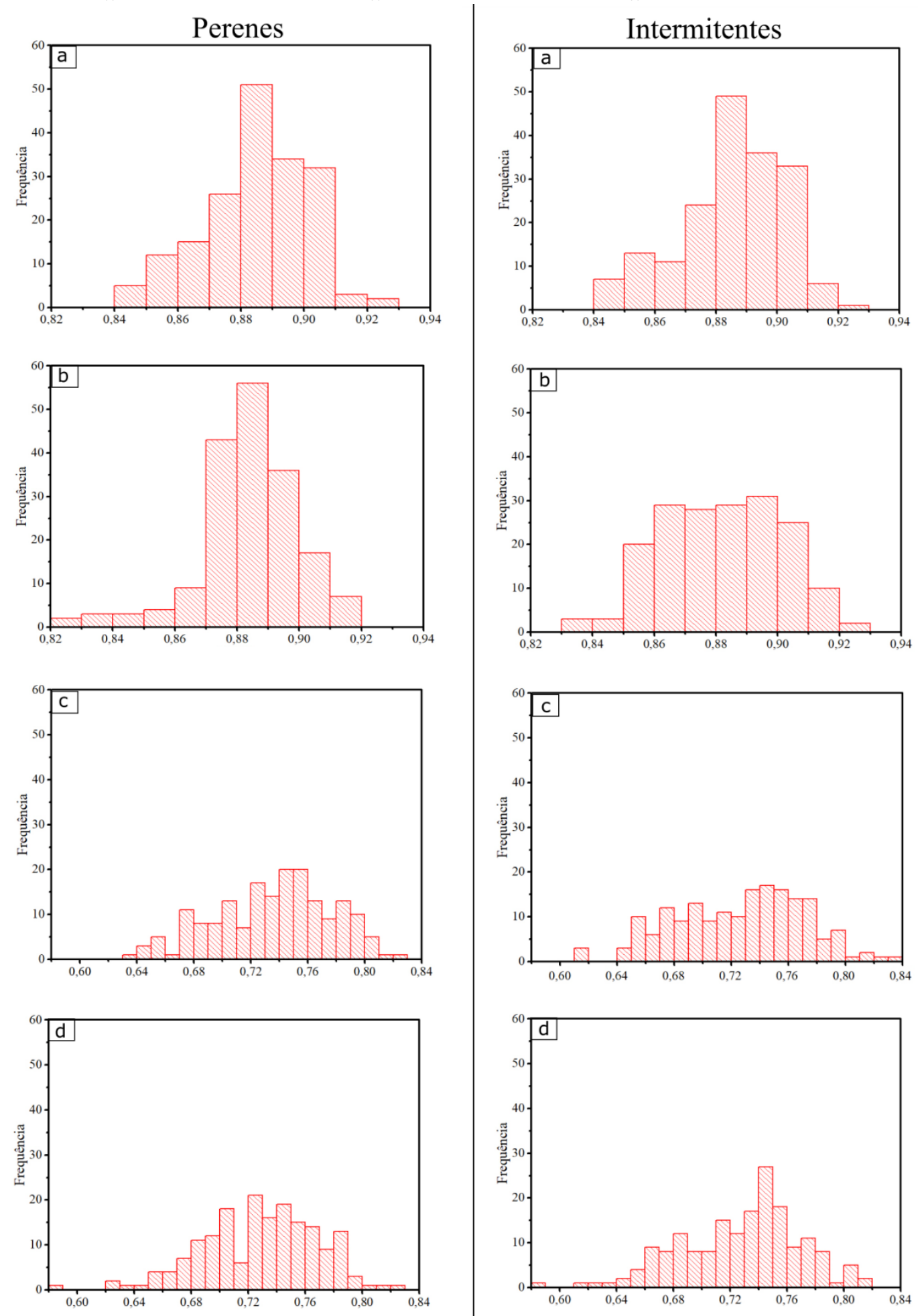

Fonte: Os autores (2020).

A variação temporal dos valores de NDVI para os buffers amostrais permitiu identificar mudanças no comportamento espectral da vegetação em relação a duas condições distintas: T1, que corresponde ao período com chuvas, temperaturas mais elevadas e vegetação com maior atividade fenológica resultando em maiores valores de NDVI e, T2, que corresponde ao final de período com diminuição de chuvas, temperaturas e vegetação com diminuição significativa na atividade fenológica, verificado pelo decréscimo dos valores de NDVI (Tabela 1). 
Tabela 1 - Medidas descritivas dos valores de NDVI conforme fluxos e períodos.

\begin{tabular}{l|c|c|c|c|c|c|c|c}
\hline Regime de fluxo & \multicolumn{3}{|c|}{ Perene } & \multicolumn{4}{c}{ Intermitente } \\
\hline Data da imagem & \multicolumn{1}{|c|}{ T1 - 8/1/2018 } & \multicolumn{2}{c|}{ T2 - 10/9/2018 } & \multicolumn{2}{c}{ T1 - 8/1/2018 } & \multicolumn{2}{c}{ T2 - 10/9/2018 } \\
\hline Distância do rio & $\mathbf{0 - 1 5}$ & $\mathbf{1 5}-\mathbf{3 0}$ & $\mathbf{0 - 1 5}$ & $\mathbf{1 5}-\mathbf{3 0}$ & $\mathbf{0 - 1 5}$ & $\mathbf{1 5}-\mathbf{3 0}$ & $\mathbf{0}-\mathbf{1 5}$ & $\mathbf{1 5}-\mathbf{3 0}$ \\
\hline Média & 0,885 & 0,883 & 0,736 & 0,728 & 0,885 & 0,881 & 0,726 & 0,727 \\
Desvio padrão & 0,016 & 0,015 & 0,041 & 0,041 & 0,017 & 0,019 & 0,045 & 0,041 \\
Soma & 159,35 & 159,07 & 132,48 & 131,20 & 159,39 & 158,75 & 130,69 & 130,92 \\
Mínimo & 0,841 & 0,824 & 0,639 & 0,583 & 0,840 & 0,836 & 0,610 & 0,587 \\
Mediana & 0,886 & 0,885 & 0,740 & 0,731 & 0,886 & 0,881 & 0,732 & 0,735 \\
Máximo & 0,924 & 0,914 & 0,822 & 0,820 & 0,924 & 0,927 & 0,830 & 0,813 \\
Teste de normalidade & 0,005 & 0,001 & 0,013 & 0,056 & 0,001 & 0,120 & 0,046 & 0,018 \\
\hline
\end{tabular}

Fonte: Os autores (2020).

Ao analisar os valores médios de NDVI dos pixels extraídos dos buffers amostrais, 0 - 15 e 15 - $30 \mathrm{~m}$, pode-se perceber que os valores entre os buffers num mesmo período e regime de fluxo são muito próximos. Para comparar a variação, em função da distância do rio para um mesmo regime de fluxo e período, foram subtraídos os valores (buffer 1 - buffer 2) e a maior diferença média foi encontrada ao longo dos rios perenes em T2 (0,008). Apesar da pequena diferença média entre os buffers, ela indica uma possível influência da proximidade do rio perene no período de estiagem (T2).

Os resultados observados de variação temporal dos valores de NDVI condizem com a literatura. Rosemback et al. (2010), encontraram para a floresta estacional semidecidual no oeste do Paraná maiores valores de NDVI no verão, com queda no inverno. No verão, o dossel vegetativo encontra-se denso, sem consideráveis interferências no substrato, enquanto nos meses de inverno ocorre redução nos valores de NDVI, devido à queda na produção de pigmentos, com interferência direta no desenvolvimento fenológico (GAIDA et al., 2016; CORDEIRO et al., 2017).

Cordeiro et al. (2017), Costa e Guasselli (2017) e Quesada et al. (2017) analisaram a variação do NDVI através de séries temporais, em áreas de floresta estacional semidecidual, e também encontraram menores valores de NDVI para o inverno e maiores no verão, corroborando, portanto com os resultados da pesquisa. Como durante os meses da primavera ocorrem os maiores índices pluviométricos a resposta da vegetação com valores de NDVI mais altos acaba sendo encontrada no início do verão, uma vez que a vegetação possui um determinado tempo de resposta à precipitação (ROSEMBACK et al., 2010).

Fu e Burgher (2015) e Santos, Baptista e Moura (2017) demonstraram que o tempo de resposta da vegetação aos valores de NDVI apresentam um delay da ordem de 28 a 30 dias em relação à ocorrência de eventos pluviométricos. Assim, considerando a data de obtenção das imagens é possível pressupor que as chuvas que ocorreram num período menor que 30 dias não influenciaram nos valores de NDVI, o que foi constatado na etapa de escolha das imagens. Conforme dados do INAPAR (2019), em Marmeleiro (PR) a precipitação acumulada entre 30 a 60 dias anteriores à imagem T1 (8/1/2018) foi de 227,8 mm e entre 30 a 60 dias anteriores à imagem T2 (10/9/2018) foi de 35,6 mm.

O decréscimo dos valores de NDVI de T1 para T2 pode ser constatado na Figura 8, na qual as áreas florestadas apresentam os maiores valores de NDVI (em verde e verde claro). Já os valores de NDVI próximos a 0 , correspondem a uma estrada de chão, ou seja, solo exposto (em amarelo e vermelho). 
Figura 8 - Mapa de área em destaque dos valores de NDVI para T1 (8/01/2018) e T2 (10/09/2018).

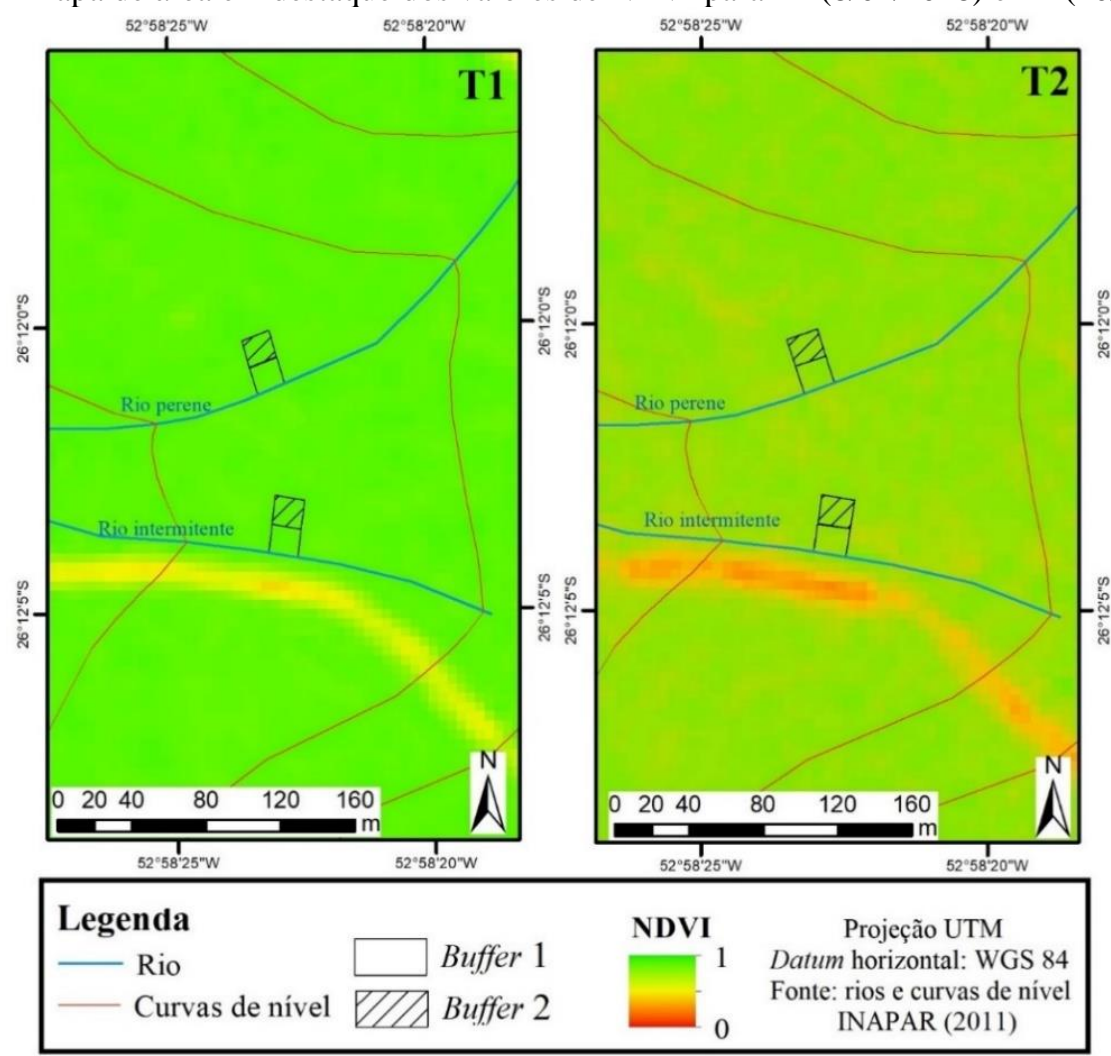

Fonte: Os autores (2020).

É importante notar que a vegetação associada, tanto a rios perenes quanto intermitentes, tende a apresentar valores de NDVI saturados para o período chuvoso (imagem T1). Contudo, a vegetação ao longo dos rios perenes apresenta uma menor dispersão em relação à média. Esse fato pode ser um indicativo da influência da drenagem, visto que, em rios intermitentes ocorre uma maior dispersão. Nesse caso, a hipótese é de que essa maior dispersão esteja associada a flutuações do NDVI derivadas das oscilações no volume de água disponível.

\subsection{Análise da diferença temporal dos valores de NDVI ( $\Delta$-NDVI)}

Os valores de $\Delta$-NDVI foram calculados a partir da subtração entre as médias dos dois períodos: T1 T2. A Tabela 2 apresenta a síntese da estatística descritiva desses valores para os buffers 1 e 2. Observa-se que os valores de $\Delta$-NDVI são maiores nas áreas adjacentes aos rios intermitentes pelo desvio padrão $(0,034 \mathrm{e}$ $0,030)$ e amplitude $(0,116$ e 0,115$)$ ao longo dos rios perenes; e desvio padrão $(0,045$ e 0,043$)$ e amplitude $(0,178$ e 0,159$)$ ao longo dos rios intermitentes.

Tabela 2 - Medidas descritivas dos valores de $\Delta$-NDVI para as áreas de buffer 1 (0-15 m) e buffer 2 (15-30 m).

\begin{tabular}{l|c|c|c|c}
\hline Regime de Fluxo & \multicolumn{2}{|c|}{ Perenes } & \multicolumn{2}{c}{ Intermitentes } \\
\hline Distância do rio & Buffer $\mathbf{1}$ & Buffer 2 & Buffer 1 & Buffer 2 \\
\hline Média & 0,149 & 0,155 & 0,159 & 0,154 \\
Desvio padrão & 0,034 & 0,030 & 0,045 & 0,043 \\
Soma & 2,985 & 3,097 & 3,188 & 3,091 \\
Mínimo & 0,102 & 0,098 & 0,080 & 0,099 \\
Mediana & 0,148 & 0,152 & 0,153 & 0,151 \\
Máximo & 0,218 & 0,213 & 0,258 & 0,258 \\
Amplitude & 0,116 & 0,115 & 0,178 & 0,159 \\
\hline
\end{tabular}

Fonte: Os autores (2020).

Os valores mínimos de $\Delta$-NDVI são bem próximos, para ambos os regimes de fluxo e buffers. Entretanto, quando analisados os valores máximos, eles são maiores para os rios intermitentes. Ao observar, respectivamente para os buffers 1 e 2, as médias $(0,149$ e 0,155$)$ e a soma $(2,985$ e 3,097) ao longo dos rios 
perenes e as médias $(0,159$ e 0,154$)$ e a soma $(3,188$ e 3,091) ao longo dos rios intermitentes, percebe-se que os valores para os buffers 2 perenes apresentam resultados mais próximos das amostras dos rios intermitentes do que em relação aos buffers 1 perenes, o que pode indicar influência do distanciamento do rio. A Figura 9 mostra a comparação das diferenças, onde $\Delta$-NDVI é maior junto aos rios intermitentes, em ambos os buffers, em 11 de 20 casos. Na referida figura, observam-se picos de diferença que se destacam frente aos demais correspondentes aos pontos intermitentes 3,5 e 17 , em que $\Delta$-NDVI ultrapassa 0,2 .

Figura 9 - Diferenças nos valores de NDVI ( $\Delta$-NDVI) entre T1 e T2 conforme o regime de fluxo e distância do rio.

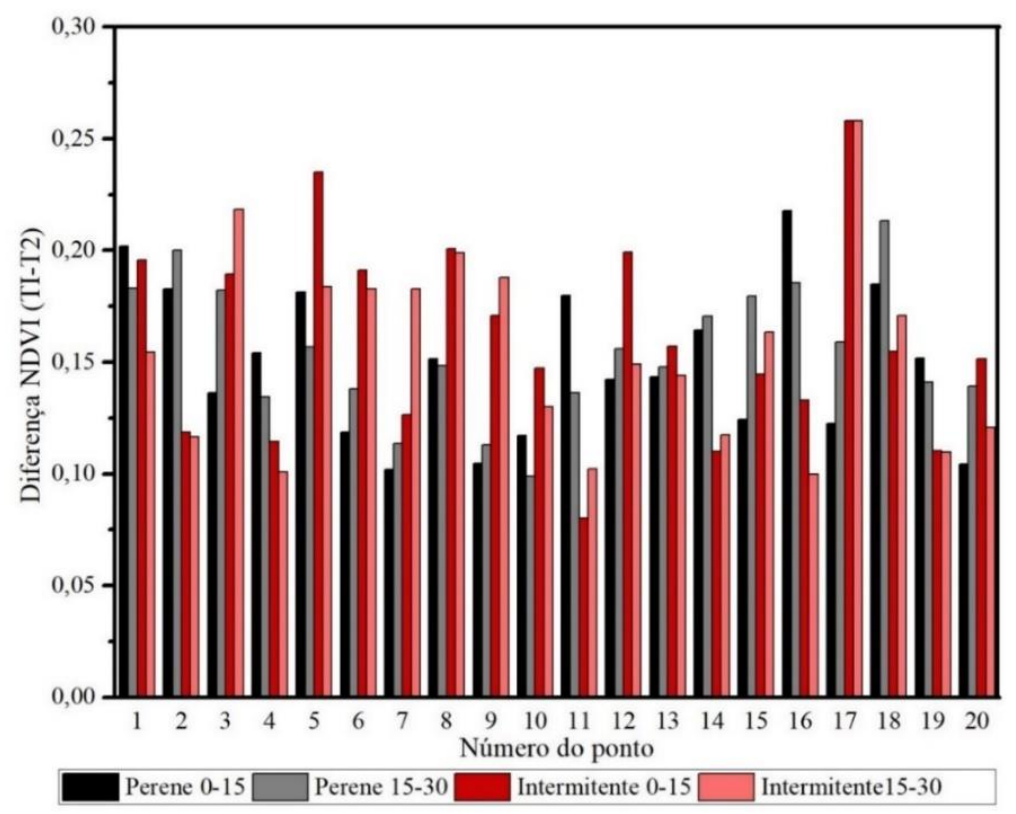

Fonte: Os autores (2020).

Na comparação entre os grupos amostrais perenes versus intermitentes, o teste U, de Mann-Whitney, apontou o valor de 172 na comparação entre buffers 1 e 204 entre buffers 2 (Tabela 3). Os valores de U muito altos evidenciam semelhança entre os 2 grupos, sendo maior entre os buffers 2. Os resultados para probabilidade exata (Exact Prob) e aproximada (Asymp. Prob) foram superiores ao nível de significância de 0,05 ; refutando a hipótese de diferença entre os grupos analisados.

Tabela 3 - Resultados do teste U para comparação do $\Delta$-NDVI entre perenes versus intermitentes.

\begin{tabular}{l|c|c|c}
\hline Distância do rio & U & Exact Prob & Asymp. Prob \\
\hline Buffer $1: 0-15(\mathrm{~m})$ & 172 & 0,4611 & 0,4569 \\
Buffer $2: 15-30(\mathrm{~m})$ & 204 & 0,9254 & 0,9245 \\
\hline
\end{tabular}

Fonte: Os autores (2020).

Dessa forma, um valor selecionado aleatoriamente de $\Delta$-NDVI, extraído de um buffer entre 0 - $15 \mathrm{~m}$, tem a probabilidade de $45,69 \%$ de ser considerado de ambos os grupos (perene ou intermitente). No caso de um valor de $\Delta$-NDVI extraído de um buffer entre 15 - $30 \mathrm{~m}$, a probabilidade de pertencer a ambos os grupos passa a ser de $92,45 \%$, o que evidencia uma maior semelhança entre os buffers 2 .

\section{CONCLUSÃO}

As diferenças entre T1 e T2, em ambos os buffers, demonstraram a variação temporal dos valores de NDVI da vegetação devido a alterações climáticas entre as duas datas estudadas, conforme pressupõem as pesquisas já realizadas sobre o assunto. Na comparação entre os buffers 1 e 2 num mesmo período, apesar dos valores absolutos de NDVI se apresentarem muito semelhantes, é possível perceber uma leve diferença nos valores dos buffers 1 perenes em T2 (período de estiagem) frente aos demais.

Apesar dos apontamentos da literatura e dos valores de NDVI apresentarem diferenças levemente maiores junto aos rios intermitentes, o teste de Mann-Witney apontou, para a área de estudo, que as diferenças 
nos valores de $\Delta$-NDVI entre os grupos perenes versus intermitentes não foram significativas.

A proximidade entre os valores de $\Delta$-NDVI denota que outros fatores podem possuir maior influência que o regime de fluxo na variação dos valores. Dessa forma, nesse estudo de caso, o NDVI não demonstrou ser útil para diferenciar a drenagem perene da intermitente, o que indica uma possível limitação do seu uso quanto a esta finalidade.

A metodologia tem potencialidade para ser testada com outros índices de vegetação na área de estudo. Cita-se como exemplo os índices RENDVI (Red-Edge Normalized Difference Vegetation Index), EVI (Enhanced Vegetation Index) e o NDWI (Normalized Difference Water Index), os quais incorporam outras bandas espectrais e podem apresentar melhor resposta que o NDVI para diferenciar o regime de fluxo em rios de primeira ordem.

\section{Agradecimentos}

À empresa Planet Labs Inc. pelo acesso aos dados RapidEye. Ao IAPAR (Instituto Agronômico do Paraná) por ceder os dados da estação meteorológica de Francisco Beltrão-PR. Ao CNPq (Conselho Nacional de Desenvolvimento Científico e Tecnológico) pelo apoio financeiro (processo 309030/2017-0).

\section{Contribuição dos Autores}

As contribuições de cada autor para o desenvolvimento deste trabalho são: conceptualização, análise formal, investigação, metodologia, administração do projeto, visualização e redação - minuta inicial, Fabiano André Marion; conceptualização, metodologia, supervisão, validação e redação - revisão e edição, Tony Vinícius Moreira Sampaio; e conceptualização, metodologia, supervisão e validação, Fábio Marcelo Breunig.

\section{Conflitos de Interesse}

Os autores declaram que não há conflitos de interesse.

\section{Referências}

ALBUQUERQUE, E. M.; ANDRADE, S. C. P.; MORAIS, H. F.; DINIZ, J. M. T.; SANTOS, C. A. C. Análise do comportamento do NDVI E NDWI sob diferentes intensidades pluviométricas no município de SousaPB. Estudos Geoambientais - revista eletrônica, v. 1, n 1, p. 1-11, 2014.

ALVARES, C. A.; STAPE, J. L.; SENTElHAS, P. C.; MORAES, G., LEONARDO, J.; SPAROVEK, G. Köppen's climate classification map for Brazil. Meteorologische Zeitschrift, v. 22, n. 6, p. 711-728, 2013. DOI.: 10.1127/0941-2948/2013/0507.

AYANLADE, A. Remote Sensing vegetation dynamics analytical methods: a review of vegetation indices techniques. Geoinformatica Polonica, v. 16, p. 11-17, 2017. DOI.: 10.4467/21995923GP.17.001.7188

BARBOSA, A. H. S.; CARVALHO, R. G.; CAMACHO, R. G. V. Aplicação do NDVI para a análise da distribuição espacial da cobertura vegetal na região Serrana de Martins e Portalegre - Estado do Rio Grande do Norte. Revista do Departamento de Geografia da USP, v. 33, p. 128-143, 2017. DOI.: 10.11606/rdg.v33i0.128171.

BARRON, O. V.; EMELYANOVA, I.; VAN NIEL, T. G.; POLLOCK, D.; HODGSON, G. Mapping groundwater-dependent ecosystems using remote sensing measures of vegetation and moisture dynamics. Hydrological Processes, v. 28, n. 2, p. 372-385, 2014. DOI.: 10.1002/hyp.9609.

BONIFACIO, R.; DUGDALE, G.; MILFORD, J. R. Sahelian rangeland production in relation to rainfall estimates from Meteosat. International Journal of Remote Sensing, v. 14, n. 14, p. 2695-2711, 1993. DOI.: 10.1080/01431169308904302. 
BOSQUILIA, R. W. D.; FIORIO, P. R.; DUARTE, S. N.; MINGOTI, R.; ZOCCHI, S. S. Diferentes produtos de Sensoriamento Remoto no mapeamento visual de drenagens e nascentes na microbacia hidrográfica do Ceveiro. Revista de Agricultura, v. 91, n. 1, p. 1-16, 2016.

BREA, M.; ZUCOL, A. F. The Paraná-Paraguay basin: geology and paleoenvironments. In: ALBERT, J. S.; REIS, R. (Ed.). Historical biogeography of Neotropical freshwater fishes. Univ of California Press, p. 69-87, 2011. DOI.: 10.1525/california/9780520268685.003.0004.

BRITO, P. V. S.; MORAIS, Y. C. B.; FERREIRA, H. S.; SILVA, J. F.; GALVINÍCIO, J. D. G. Análise comparativa da umidade da vegetação de áreas de caatinga preservada, agricultura irrigada e sequeiro. Journal of Environmental Analysis and Progress. v. 2 n. 03, p. 493-498, 2017. DOI.: 10.24221/jeap.2.4.2017.1481.493-498.

CALDANA, N. F. da S.; MARTElÓCIO, A. C.; RUDKE, A. P.; NITSCHE, P. R.; CARAMORI, P. H. Frequência, intensidade e variabilidade pluviométrica na Mesorregião Sudoeste Paranaense. Revista Brasileira de Climatologia, n. 15, v. 25, p. 161-181, 2019. DOI.: 10.5380/abclima.v25i0.64516.

CORDEIRO, A. P. A.; BERLATO, M. A.; FONTANA, D. C.; MELO, R. W. D.; SHIMABUKURO, Y. E.; FIOR, C. S. Regiões homogêneas de vegetação utilizando a variabilidade do NDVI. Ciência Florestal, v. 27, n. 3, p. 883-896, 2017. DOI.: 10.5902/19805098286.

COSTA, L. C. B. da; GUASSELLI, L. A. Dinâmica sazonal de remanescentes da Mata Atlântica, a partir de séries temporais NDVI/MODIS. Geo UERJ, n. 30, p. 214-239, 2017. DOI.: 10.12957/geouerj.2017.15868.

DONOHUE, R. J.; MCVICAR, T. R.; RODERICK, M. L. Climate-related trends in Australian vegetation cover as inferred from satellite observations, 1981-2006. Global Change Biology, v. 15, n. 4, p. 10251039, 2009. DOI.: 10.1111/j.1365-2486.2008.01746.x.

EXELIS. Fast Line-of-sight Atmospheric Analysis of Hypercubes (FLAASH). 2015. Disponível em: <http://www.exelisvis.com/docs/FLAASH.html>. Acesso em: 7 out. 2019.

FERNÁNDEZ, D. C. J.; VALERIANO, M. M.; ZANI, H.; ANDRADES FILHO, C. O. Extração automática de redes de drenagem a partir de modelos digitais de elevação. Revista Brasileira de Cartografia, v. 64, n. 5, p. 619-634, 2012.

FRITZ, K. M.; HAGENBUCH, E.; D'AMICO, E.; REIF, M.; WIGINGTON JR, P. J.; LEIBOWITZ, S. G.; NADEAU, T. L. Comparing the extent and permanence of headwater streams from two field surveys to values from hydrographic databases and maps. Journal of the American Water Resources Association, v. 49, n. 4, p. 867-882, 2013. DOI.: 10.1111/jawr.12040.

FU, B.; BURGHER, I. Riparian vegetation NDVI dynamics and its relationship with climate, surface water and groundwater. Journal of Arid Environments, v. 113, p. 59-68, 2015. DOI.: 10.1016/j.jaridenv.2014.09.010.

GAIDA, W.; BREUNIG, F. M.; GALVÃO, L. S.; TELES, T. S.; BALBINOT, R. Variações da reflectância e dos índices de vegetação em função dos parâmetros da modelagem topográfica no Parque Estadual do Turvo, Rio Grande do Sul, Brasil. Investigaciones geográficas, n. 91, p. 105-123, 2016. DOI.: 10.14350/rig.52159.

GONZALEZ-FERRERAS, A. M.; BARQUIN, J. Mapping the temporary and perennial character of whole river networks. Water Resources Research, v.85, p. 57-66, 2017. DOI.: 10.1002/2017WR020390.

HUETE, A. R.; DIDAN, K.; SHIMABUKURO, Y.; RATANA, P.; SALESKA, S. R.; HUTYRA, L. R.; YANG, W.; Amazon rainforests green-up with sunlight in dry season. Geophysical Research Letters, v. 33, n. 6, 2006. DOI.: 10.1029/2005GL025583.

IAPAR - INSTITUTO AGRONÔMICO DO PARANÁ. Dados meteorológicos diários da estação de Francisco Beltrão - código 02643012. Londrina, 2019. Arquivo em Exell.

IBGE - INSTITUTO BRASILEIRO DE GEOGRAFIA E ESTATÍSTICA. Manual técnico da vegetação brasileira. 2 ed. Rio de Janeiro: 2012. 269 p. 
INAPAR - INSTITUTO DAS ÁGUAS DO PARANÁ. Base Hidrográfica do Paraná - 1:50.000. Curitiba PR, 2011.

INAPAR - INSTITUTO DAS ÁGUAS DO PARANÁ. Sistema de Informações hidrológicas: Estação Pluviométrica de Marmeleiro. 2019. Disponível em: <http://www.aguasparana.pr.gov.br/pagina264.html>. Acesso em: 20 set. 2019.

JAYASURIYA, M. T.; GERMAIN, R. H.; BEVILACQUA, E. Stumpage opportunity cost of riparian management zones on headwater streams in Northern Hardwood Timberlands. Forest Science, v. 65, n. 1, p. 108-116, 2018. DOI.: 10.1093/forsci/fxy035.

JENSEN, J. R. Sensoriamento remoto do ambiente: uma perspectiva em recursos terrestres. Tradução $2^{\circ}$ ed.: José Carlos N. Epiphanio (coordenador); Antonio R. Formaggio; Athos R. Santos; Bernardo F. T. Rudorff; Cláudia M. Almeida; Lênio S. Galvão. São José dos Campos: Parêntese. 2009. 598p.

LARNED, S. T.; DATRY, T.; ARSCOTT, D. B.; TOCKNER, K. Emerging concepts in temporary-river ecology. Freshwater Biology, v. 55, n. 4, p. 717-738, 2010. DOI.: 10.1111/j.1365-2427.2009.02322.x.

LIMA, K. C.; CUNHA, C. M. L. Atualização cartográfica da rede de drenagem para estudo geomorfológico de rios intermitentes e efêmeros do semiárido. Revista Brasileira de Cartografia, v. 66, n. 1, p. 127-136, 2014.

LIN, W.; CHOU, W.; LIN, C.; HUANG, P.; TSAI, J. Automated suitable drainage network extraction from digital elevation models in Taiwan's upstream watersheds. Hydrological Processes. v. 20, p. 289-306, 2006. DOI.: 10.1002/hyp.5911.

MACHADO, T. S.; CAIONI, C.; FERNANDES, R. S.; NEVES, R. J.; NEVES, S. M. A. Análise de NDVI e NDWI em diferentes intensidades pluviométricas para a bacia hidrográfica do rio do Cachoeirinha - Mato Grosso, Brasil. In: SIMPOSIO DE GEOTECNOLOGIAS NO PANTANAL, 5., 2014, Campo Grande, MS. Anais... Embrapa Informática Agropecuária/INPE, Campinas: Embrapa/INPE, 2014. p 690-699. 1 DVD.

PONZONI, F. J.; SHIMABUKURO, Y. E.; KUPLICH, T. M. Sensoriamento remoto no estudo da vegetação. $2^{\circ}$ ed. São Paulo: Oficina de Textos, 2012. 176 p.

QUESADA, H. B.; REDONDO, G.; VERNASQUI, L. G.; MAGNONI, P. H. J.; ARANTES, E. J. Análise da vegetação ripária em bacia hidrográfica utilizando Índice de Vegetação Normalizada (NDVI) no município de Maringá-PR. Geo UERJ, n. 31, p. 439-455, 2017. DOI.: 10.12957/geouerj.2017.26737.

RAPIDEYE AG SATELLITE. Imagery Product Specifications, Version 6.1. Planet: 2016. Disponível em: <https://www.planet.com/products/satellite-imagery/files/160625-RapidEye\%20Image-ProductSpecifications.pdf>. Acesso em: 20 set. 2019.

RODERJAN, C. V.; GALVÃO, F.; KUNIYOSHI, Y. S.; HATSCHBACH, G. G. As unidades fitogeográficas do estado do Paraná, Brasil. Ciência \& Ambiente, v. 24, n. 1, p. 75-92, 2002.

ROSEMBACK, R.; FERREIRA, N. J.; SHIMABUKURO, Y. E.; CONFORTE, J. C. Análise da dinâmica da cobertura vegetal na região Sul do Brasil a partir de dados MODIS/Terra. Revista Brasileira de Cartografia, n. 62, p. 401-416, 2010.

ROUSE, J. W.; HAAS, R. H.; SCHELL J. A.; DEERING, D. W. Monitoring vegetation systems in the great plains with ERTS. In: EARTH RESOURCES TECHNOLOGY SATELLITE-1 SYMPOSIUM, 3., Washington, D.C., 1973. Anais... Washington, D.C.: NASA. Goddart Space Flight Center, 1973a. v.1, p. 309-317.

SAMPAIO, T. V. M.; AUGUSTIN, T. H. R. R. Variáveis auxiliares para o mapeamento da rede de drenagem: correlação espacial entre nascentes, unidades de relevo e litotipos na bacia hidrográfica do rio Benevente - ES. GEOUSP - Espaço e Tempo, São Paulo, v. 18, n. 3, p. 624-634, 2014. DOI 10.11606/issn.21790892.geousp.2014.90071.

SANTOS, L. J. C.; OKA-FIORI, C.; CANALI, N. E.; FIORI, A. P.; SILVEIRA, C. T. da; SILVA, J. M. F. da. Morphostructural mapping of Parana state, Brazil. Journal of Maps, v. 5, n. 1, p. 170-178, 2009. DOI.: 
10.4113/jom.2009.1059.

SANTOS, C. V. B. dos S.; BAPTISTA, G. M. de M.; MOURA, M. S. B. de. Seasonality of Vegetation Indices in different land uses in the São Francisco Valley. Journal of Hyperspectral Remote Sensing, v. 7, n. 3, p. 158-167, 2017. DOI.: 10.29150/jhrs.v7.3.p158-167.

SOUSA, M. S. de; SAMPAIO, T. V. M. Influência da acurácia de completude na delimitação de áreas de preservação permanente. Confins, 35, 2018. DOI.: 10.4000/confins.13245.

TOMAZONI, J. C.; GUIMARÃES E.; GOMES, T. C.; SILVA, T. G da. Uso de Modelo Digital de Elevação gerados a partir do ASTER GDEM e SRTM para caracterização de rede de drenagem. Revista Brasileira de Geografia Física, n 02. p. 365-376. 2011. DOI.: 10.26848/rbgf.v4.2.p365-376.

WILLIAMSON, T. N.; AGOURIDIS, C. T.; BARTON, C. D.; VILLINES, J. A.; LANT, J. G. Classification of ephemeral, intermittent, and perennial stream reaches using a TOPMODEL-based approach. Journal of the American Water Resources Association, v. 51, n. 6, p. 1739-1759, 2015. DOI.: 10.1111/17521688.12352.

XUE, J.; SU, B. Significant remote sensing vegetation indices: a review of developments and applications. Journal of Sensors, v. 2017, 2017. DOI.: 10.1155/2017/1353691.

\section{Biografia do autor principal}

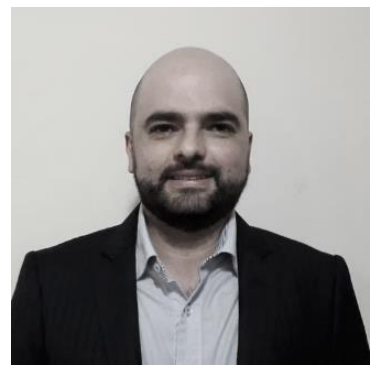

Fabiano André Marion é natural de Sobradinho, RS - Brasil. Possui graduação em Geografia-bacharelado (2007) e mestrado em Geomática (2009), ambos concluídos pela Universidade Federal de Santa Maria, em Santa Maria, RS. Tem experiência na área de geoprocessamento aplicado aos recursos hídricos e em sensoriamento remoto da vegetação. Atualmente cursa doutorado em Geografia pela Universidade Federal do Paraná, em Curitiba - PR. É professor assistente no curso de Geografia da Universidade Estadual do Oeste do Paraná, Campus de Francisco Beltrão, PR, desde 2013, onde atuou por 4 anos como professor colaborador. 